\title{
Vojko Strabounik
}

\section{Vrline in transhumanistična nadgradnja človeka}

\section{Virtues and Transhumanist Human Augmentation}

Pov₹̨etek: Moralni transhumanizem je program, ki si prizadeva za moralno izboljšanje oziroma nadgradnjo človeka s pomočjo sodobnih tehnologij. V prispevku se posvečamo etičnim vprašanjem in izzivom, ki jih transhumanizem odpira - še posebej vprašanju, ali je mogoče nadgraditi tudi etične vrline. Moralni transhumanizem se namreč za doseganje tega cilja opira predvsem na gensko tehnologijo. Ob tem izpostavljamo, da je ena izmed temeljnih značilnosti človeške moralne misli občutljivost na razloge. Nadgradnja etični vrlin bi to občutljivost (lah-

ko) zmanjšala, obenem pa bi okrnila tudi avtonomijo in svobodo posameznika.

Ključne besede: etika, transhumanizem, vrline, razlogi, avtonomija

Abstract: Moral transhumanism is a project that seeks to morally enhance or upgrade human beings through the use of modern technologies. The paper addresses the ethical issues and challenges posed by transhumanism, and especially the question of whether ethical virtues can be enhanced. Moral transhumanism relies primarily on genetic technology to achieve this goal. It should be indicated that one of the fundamental characteristics of human moral thought is sensitivity to reasons. Enhancing ethical virtues would diminish this sensitivity while at the same time, also compromising the autonomy and freedom of the individual. Keywords: ethics, transhumanism, virtues, reasons, autonomy

\section{Uvod}

Prispevek obravnava vprašanje kreposti oziroma vrlin v luči transhumanističnega projekta izboljšanja ali nadgradnje človeka. Pri tem se nekoliko ožje posveča vidiku etičnih vrlin in tako imenovanemu moralnemu transhumanizmu. $V$ drugem razdelku predstavlja kratek oris etičnih izzivov, ki jih transhumanizem prinaša. $V$ tretjem razdelku obravnava vprašanje vrlin in predstavlja posamezne argumente, $v$ luči katerih transhumanistični projekt nadgradnje človeka podpira tudi nadgradnjo vrlin. Hkrati izpostavlja nekatere pomisleke, ki jih zagovarjanje take nadgradnje odpira. $V$ četrtem razdelku se prispevek ukvarja z vprašanjem etične vrlosti in z enim izmed konkretnih predlogov nadgradnje etičnih vrlin, ki se osredotoča na tako 
imenovano genetsko vrlino/genetsko vrlost. Posebej so izpostavljene vrline resnicoljubnosti, pravičnosti in skrbi kot glavni cilji transhumanističnega izboljšanja. $\mathrm{V}$ zaključku je podan argument proti takšni moralni nadgradnji človeka, ki temelji na premislekih o pomembnosti občutljivosti na razloge in avtonomijo posameznika.

\section{Etični izzivi transhumanizma}

Transhumanizem odpira številna etična vprašanja, ki jih lahko razdelimo v dva večja sklopa. Prvi sklop se nanaša na etični status tehnologij, ki jih transhumanizem zagovarja, posebej umetne inteligence in pridruženih sistemov, ter na vprašanje njihovega delovanja z vidika moralnosti. To vprašanje je pomembno zato, ker transhumanizem zagovarja spoj oziroma preplet teh tehnologij s človekom. Primer takšnega tesnega spoja so na primer androidni roboti. V okviru tega sklopa se odpirajo vprašanja, ali lahko takšnim sistemom pripišemo moralni status in kako jih lahko vpnemo v mrežo moralnih obveznosti. Posebej za slednji del vprašanja niti ni potrebno posegati v bolj oddaljeno prihodnost, ampak zadeva tudi vprašanja, ki jih postavlja že obstoječe stanje tehnologije ter njena uporaba - vzemimo za primer sisteme umetne inteligence, ki odločajo o vprašanjih ocene tveganj pri zavarovanjih, odobritvi pogojnega izpusta (npr. sistem Compas v ZDA), določitvi višine varščine ali odobritvi bančnega kredita. Ne gre za to, da bi jim v vsakem primeru pripisovali poseben moralni status kot moralnim delovalcem, vsekakor pa se je smiselno vprašati, kakšno raven transparentnosti lahko $v$ teh postopkih od takšnih sistemov pričakujemo (kljub njihovi zanesljivosti oziroma natančnosti, ki morda prekaša človeške odločevalce) in kako je z odgovornostjo v primeru napak oziroma zmot (Cruz 2019).

Glede vprašanja moralnega statusa sistemov umetne inteligence lahko opozorimo tudi na razlikovanje med splošnimi in posebnimi sistemi umetne inteligence (Bostrom in Yudkowsky 2014, 318). Slednji (osredotočeni zgolj na eno nalogo ali razsežnost delovanja in pri kognitivnih virih, kot so spomin, moč oziroma hitrost procesiranja ter sposobnost osredotočenosti (skoraj) neomejeni) že obstajajo in v mnogočem presegajo meje človeških sposobnosti, in sicer zlasti pri (linearnem) vzročno-posledičnem procesiranju. Prvi so medtem šele v razvoju, a hkrati odpirajo precej pomembnejša etična vprašanja. Vzemimo samo vprašanje zavesti ali čutečnosti: ali jim lahko pripišemo oznako, da gre za nekaj, kar je zmožno čutiti - na primer empatijo, žalost ali bolečino oziroma trpljenje. Ta vidik je pomemben, saj poleg razvoja teh tehnologij v vojaške namene po pomenu in obsegu izstopa predvsem industrija androidnih robotov, katerih vloga je/ bo nega ter skrb za starajoče se prebivalstvo, ki ni več zmožno povsem samostojnega življenja, ter za ostale skupine, potrebne posebne skrbi. Ravno zato je čutečnost eden izmed možnih ciljev razvoja takšnih tehnologij, saj bi to predstavljalo prednost pred drugimi tehnologijami za pomoč.

Naslednji etično pomemben vidik, ki ga odpira možnost splošne umetne inteligence, predstavljajo odnosnostne in družbene razsežnost takšne tehnologije, ki jih zavezujejo sorodne etične norme kot človeško življenje (npr. pravičnost, odgovornost, transparentnost, odsotnost korupcije in pristranskosti, predvidljivost), saj bodo 
ti sistemi delovali njegovem družbenem kontekstu. Bostrom in Yudkowsky (2014, 317) to smiselno ponazarjata $z$ mislijo, da pri izdelavi robotske roke seveda pride $v$ poštev tudi to, da ne bo zlahka poškodovala človeka, vendar to ne odpira nobenih radikalno novih etičnih vprašanj, ki ne bi zadevala tudi vseh drugih izdelkov, se pravi vprašanj varnosti za uporabnika. Pri algoritmih umetne inteligence, ki bodo nadomeščali človeka kot odločevalca in delovalca kot del družbene razsežnosti, pa se odpirajo povsem nova etična vprašanja. Odpirajo se tudi vprašanja same etične zasnove sistemov umetne inteligence (tudi v kontekstu tega, da bi s temi sistemi lahko nadgradili človeka), saj ne gre zgolj za to, da bi jim postavili etične omejitve (to se glede na zasnovo teh sistemov, način njihovega delovanja in zmožnosti samostojnega razvoja tako ali tako zaenkrat kaže kot neizvedljivo), ampak morajo biti ti sistemi sami sposobni misliti in delovati etično (Bostrom in Yudkowsky 2014, 320). Sem spada tudi vprašanje (samo)reprodukcije takšnih sistemov (njihove zmožnosti namreč bistveno presegajo človeške reproduktivne omejitve), pa tudi z njim povezano vprašanje superinteligence, ki bi bila lahko rezultat takšnega eksponentnega in samostojnega razvoja - če bi ta začel uhajati izpod človeškega nadzora.

Drugi sklop obsega vprašanja, kje so meje (možnosti, smiselnosti, sprejemljivosti) transhumanističnega projekta izboljšanja in nadgradnje človeka ob uporabi genske tehnologije, nanotehnologije, umetne inteligence in drugih (podobnih) tehnologij. Eno izmed vprašanj glede možnosti se ne tiče samo mej te tehnologije, pač pa tega, ali v takšnih primerih sploh še lahko govorimo o človeškemu bitju (Globokar 2018, 357-358). Transhumanizem tako govori o transčloveku oziroma postčloveku kot bitju, ki ima ob pomoči tehnologije izboljšanja vsaj eno izmed trans- oziroma postčloveških lastnosti. Znotraj te razprave je pomembna razlika med terapijo in nadgradnjo. Terapijo predstavljajo posegi v človeka, ki posamezniku omogočajo tako raven delovanja, da se ta še razume kot za človeška bitja normalna ali običajna (takšen poseg na področje človekove moralnosti bi na primer predstavljal tehnološki poseg za zvišanje ravni empatije na običajno raven, ki bi psihopatom omogočal zmožnost običajne moralne presoje, motivacije in delovanja). Nadgradnjo oziroma izboljšanje človeka pa predstavljajo posegi, ki raven delovanja povzdignejo nad običajne človeške ravni-za nekajkrat, nekaj desetkrat ali celo onkraj tega (takšen primer bi predstavljala nadgradnja človeka s sistemom umetne inteligence Watson, ki je premagal najboljše človeške igralce kviza Jeopardy in ima med drugim sposobnost, da v sekundi prebere milijon knjig in procesira informacije $v$ njih). Takšno radikalno izboljšanje človekovih miselnih sposobnosti v okviru transhumanizma napoveduje denimo Kurtzweil (Agar 2010), za področje moralnosti pa bi takšen primer predstavljal dvig empatije na raven, ki bi predstavljala povsem predrugačeno človekovo motivacijo in delovanje. $V$ zvezi s tem sklopom se tako odpirajo etična vprašanja o dopustnosti spreminjanja človekove narave oziroma preseganju te narave glede avtonomije, omejene svobode, izgube avtentičnosti ipd.

\section{Vrline in nadgradnja človeka}

$V$ tem razdelku bo $v$ ospredju vprašanje spoznavnih in etičnih vrlin $v$ kontekstu obravnave transhumanističnega projekta, nadgrajenih človekovih zmožnosti in 
umetne inteligence. Gre za zanimivo raziskovalno vprašanje, ki v okviru transhumanizma še ni bilo posebej raziskano (razen na obronkih), saj je bilo do sedaj govora predvsem o človekovi naravi v celoti ali o posameznih vidikih človekovega življenja, pri čemer so v ospredju predvsem človekove sposobnosti. Pri sodobni vrlinski teoriji ne gre zgolj za obnovitev antične tradicije vrlinske etike in vrlinske epistemologije, temveč za celostni pristop, ki vključuje tudi empirična spoznanja kognitivnih znanosti. Vsako raziskovanje transhumanizma in vprašanja nadgradnje človekovih zmožnosti terja razmislek prav v takšnem širšem okviru.

Vrline so hvalevredne oziroma dobre značajske lastnosti v obliki relativno trdnih in trajnih dispozicij za delovanje (oziroma tudi dispozicij za zaznavanje, pričakovanje, vrednotenje, čustvovanje, izbiranje, odzivanje ipd.), ki človeku pomagajo dosegati zanj pomembne cilje (na primer srečnost, dobro življenje, resnico, razumevanje). Vrline imajo vsaj štiri različne vidike oziroma gradnike, in sicer miselnega, čustvenega, motivacijskega in delovanjskega. Če si ogledamo primere posameznih vrlin, kot so pogumnost, resnicoljubnost, pravičnost, hvaležnost, ponižnost ipd., lahko ugotovimo, da vključujejo posameznikova jedrna prepričanja o njihovi smotrnosti, njegovo čustveno zadržanost ali naravnanost do vrlosti, motivacijo za delovanje v skladu s temi vrlinami ter tudi dejansko delovanje v skladu z njimi (Hursthouse in Pettigrove 2018; Žalec 2010, 157-169). Ob tem lahko sledimo tudi uveljavljeni delitvi vrlin na spoznavne oziroma intelektualne in etične oziroma moralne vrline, ki je znana že vsaj od Aristotela naprej. „Na isti način se delijo tudi vrline: ene imenujemo razumske, druge nravstvene. Med razumske vrline spadajo modrost, bistrost in pametnost, med nravstvene pa plemenitost in umerjenost. Zakaj če govorimo o nraveh, ne pravimo, da so modre ali bistre, ampak da so blage ali umerjene. Modrega človeka hvalimo zaradi njegove lastnosti, hvalevredne lastnosti pa imenujemo vrline." (Aristotel 2002, 73) Intelektualne vrline so nam po Aristotelu deloma dane ob rojstvu, deloma pa se jih kasneje lahko naučimo, medtem ko so moralne vrline pridobljene predvsem z navado oziroma z njihovim kultiviranjem v okviru vzgoje ali udejstvovanja. Oboje so oblikovane na temelju človekove narave, ne pa dane s to naravo (Aristotel 2002, 75-76). To je tudi točka, na katero se opira transhumanizem.

Ker so vrline pomemben gradnik človekove osebnosti in podlaga njegovega delovanja, jih seveda tudi transhumanizem s svojim projektom nadgradnje oziroma izboljšanja človeka ni zaobšel. Transhumanizem si v okviru cilja izboljšanja človeka $z$ vidika kognitivnih sposobnosti in moralnosti tako med drugim prizadeva za nadgradnjo človekovih vrlin (Persson in Savulescu 2008). Znotraj transhumanistične misli sicer srečamo več najrazličnejših predlogov moralne nadgradnje človeka (moralni transhumanizem); njihov cilj je človeška bitja narediti bolj moralna. Ti predlogi se razlikujejo glede na predlagana sredstva za nadgradnjo in ciljne fenomene te nadgradnje (Daniels 2009, 40; Caplan 2009, 206; Savulescu 2009, 213-214; Douglas 2008; Willows 2017, 178). Del transhumanističnega projekta predstavlja tudi nadgradnja človeka z vidika etičnih kreposti (Walker 2009). Če je pri intelektualnih sposobnostih in s tem tudi pri intelektualnih vrlinah izpostavljena predvsem tehnologija prepletenosti nadgrajenega človeka s sistemi umetne inteligence, sta najpogo- 
stejša pristopa na področju moralnih kreposti genski inženiring in napredna farmakologija. Vendar vrsta tehnoloških sredstev za izboljšanje etičnih vrlin pri tem vprašanju ni osrednji problem. Pomislek, ki je lahko relevanten, je, da se moralna krepost pri teh načinih izboljšanja človeka ne pridobi na podlagi vzgoje in ponavljajočih se dejanj, temveč na drugačen način. A to še ni nujno razlog, da bi jim lahko nasprotovali, zlasti, če ta način drugače moralno ni sporen in če je končni cilj zares dobro tako posameznika kot družbe kot celote. V tem smislu Willows (2017, 180-181) celo trdi, da bi morala teologija načeloma moralni transhumanizem podpirati.

\section{Etične kreposti v luči možnosti nadgradnje človeka}

Kot značilnemu primeru transhumanističnega zagovora izboljšanja človeka z vidika vrlin bomo v jedru tega razdelka sledili Marku Walkerju (2009) in njegovemu predlogu (transhumanistične) nadgradnje etičnih vrlin (kot dopolnilo in podaljšek razvoja oziroma napredka, ki ga lahko prehodijo vzgoja in družbene spremembe). Walker svoj predlog umešča v splošnejši program genetske vrlosti (angl. genetic virtue program). Gre za predlog za vplivanje na moralnost (etično naravo človeka) preko genskih podlag našega delovanja, pri čemer je to vplivanje dopolnilno in podpira siceršnja prizadevanja za (bolj) etično delovanje. Ker geni oziroma genska osnova vplivajo na človeško vedênje, lahko poseganje v posameznikove gene vpliva na njegovo vedenje. »Inženirska genetska vrlost« se lahko doseže na primer z predimplantacijsko genetsko diagnozo za izbiro zarodkov (tehnika je danes že na voljo: gre za izbiranje zarodkov na podlagi najboljše možne genske podlage) ali z genetsko spremenjenimi zigotami (tehnika, ki je še v razvoju) (26-27).

Izhodišča tega predloga temeljijo na več predpostavkah. Prva je ta, da je človeška narava moralno pomanjkljiva in jo je mogoče izboljšati. Druga predpostavka je, da o vrlinah kot relativno stabilnih dispozicijah za delovanje sploh lahko govorimo in posledično, da je pri vrlinah odločilen najprej in predvsem delovanjski vidik (za razliko od miselnega, čustvenega ali motivacijskega). Tema predpostavkama se pridružujeta še dve: da imajo vsaj nekatere vrline (ali hibe) dedno oziroma gensko komponento ter da lahko prepoznamo in nadzorujemo gene, ki so za to dedno komponento odgovorni (28-31).

Po zagovoru izpolnjenosti teh predpostavk sledi glavni Walkerjev argument za etično sprejemljivost programa genetske vrlosti. Če sta biotehnologija in genska tehnologija moralno sprejemljivi za neetične oziroma druge izboljšave človeka in glede na to, da vsekakor imamo za moralno sprejemljiva negenetska sredstva (kot na primer vzgojo, izobraževanje in socializacijo) moralnega izboljševanja človeka ter povečevanja skupnega dobrega (za ustvarjanje boljšega sveta), potem ni nobenega načelnega razloga, da ne bi za dosego tega cilja uporabili (tudi) programa genetske vrlosti. Vsak morebiten razlog, ki bi ga izpostavili kot razlog proti takšni nadgradnji, bi enako štel kot razlog proti moralnemu izboljšanju v okviru vzgoje in socializacije, slednjih dveh pa ne moremo razumeti kot moralno nedopustnih ali vprašljivih (34). Za sam predmet izboljšanja Walker predlaga vrline resnicoljub- 
nosti, pravičnosti in skrbi, kajti pri teh naj bi dosedanje empirične raziskave tako človeka kot tudi višje razvitih živali nakazovale, da imajo vse te tri vrline poudarjeno gensko komponento in jih je torej najenostavneje izboljšati.

Walker sam sicer pri takšnem programu izpostavlja dva osrednja pomisleka. Prvi je povezan s ciljem moralnega izboljšanja človeka in posebej še sveta. Vprašamo se lahko, kako sprejemljiv cilj izboljšanje sveta sploh je in kako ga zares uokviriti (to je, ali obstaja enoznačno razumevanje, kaj vse obsega). Tu Walker odgovarja, da isto vprašanje zadeva tudi vzgojo samo, kajti tudi tam je naš cilj izgradnja moralno zrele osebe $z$ namenom prispevanja $\mathrm{k}$ boljšemu svetu - torej je takšno pojmovanje dobrega in boljšega sveta dovolj enoznačno oziroma univerzalno. Drugi pomislek je, ali takšen program genetske vrlosti dejansko vodi k vrlosti ali zgolj k imitaciji vrlosti - glede na to, da so v ospredju predvsem delovanjski vidiki etične vrlosti? Walker odgovarja, da to ni zgolj posebnost programa genetske vrlosti, ampak da podobno razumevanje vrlosti zagovarja tudi posledicistični oziroma utilitaristični pogled na moralnost, kjer je v ospredju predvsem dispozicija za delovanje v smeri kar najboljših posledic naših ravnanj. Vse, kar je moralno pomembno oziroma moralno šteje, so posledice naših ravnanj. K temu odgovoru pridružuje še premislek, da bi znanstveni in tehnološki napredek genske tehnologije morda lahko zaobšel omejitev zgolj na delovanjski vidik in omogočal izboljšanje vrlin v širšem smislu, kar vključuje tudi izboljšanje prepričanj, namenov, motivacije in čustvovanja (Walker 2009, 36-38).

Bostrom in Sandberg $(2009,396)$ izpostavljata širši nabor lastnosti posameznikov, ki naj bi bile takšne, da prispevajo k skupnemu dobremu in tako spadajo $v$ okvir legitimnega obzorja transhumanističnega projekta izboljšanja. Gre za razširjeni altruizem, vestnost in poštenost, skromnost in ponižnost, izvirnost, iznajdljivost in neodvisno razmišljanje, civilni pogum, poznavanje in dobro presojo o javnih zadevah, empatijo in sočutje, negovanje čustvenosti in skrbi, pravično občudovanje in spoštovanje, samokontrolo in sposobnost nadzora nad nasilnimi impulzi, močan občutek pravičnosti, odsotnost rasnih predsodkov, odsotnost nagnjenosti k zlorabi drog, zadovoljstvo ob uspehu in razcvetu soljudi, spodobnost za uporabne oblike gospodarske produktivnosti, zdravje, odpornost in dolgo življenjsko dobo. Za nadgradnjo mora vsaka od teh lastnosti sicer prestati še test evolucijske optimizacije, pri katerem lahko zanjo pojasnimo, zakaj se v evolucijskem procesu še ni sama razvila do ravni nadgradnje, in zakaj ni ovir, da ne bi v sedanjosti predstavljala prednosti. Če posamezna lastnost ta test prestane, potem »imamo primer, za katerega imamo razlog, da mislimo, da modrost narave ni dosegla tega, kar je najbolje za našo družbo in da lahko sami to naredimo bolje« (Bostrom in Sandberg 2009, 397). Se pa njun program pri sredstvih za moralno izboljšanje ne omejuje le na gensko tehnologijo, pač pa se lahko takšno izboljšanje navezuje na katero koli tehnologijo, ki bi lahko etično izboljšala človeka oz. pozitivno vplivala na njegovo krepost.

Cilj etičnega transhumanizma je torej jasen: razviti in uporabiti vsakršno tehnologijo nadgradnje človeka, ki bi etično človeka izboljšala in s tem prispevala $\mathrm{k}$ moralnemu napredku sveta. Pri tem so eden izmed osrednjih predmetov takšne nadgradnje človekove vrline kot notranja podlaga njegovega delovanja. 


\section{Zaključek}

$\checkmark$ zaključnem razmisleku o nadgradnji etičnih vrlin v okviru transhumanističnega projekta izhajamo iz vzporejanja človeških kognitivnih zmožnosti in razvoja zmožnosti, ki jih omogoča umetna inteligenca ter druge tehnologije nadgradnje človekovih kognitivnih sposobnosti -pospešen kognitivni razvoj s pomočjo biotehnologije, genetskega inženiringa, nanotehnologije, informacijskih tehnologij idr. Posebej lahko izpostavimo vidik presoje in delovanja na podlagi razlogov ter vidik posameznikove avtonomije kot jedra etičnega ravnanja.

$Z$ vidika moralnih in spoznavnih vrlin se namreč zastavlja temeljno vprašanje, kaj so značilno človeške oblike mišljenja in katere so njihove temeljne značilnosti. Eden izmed naukov, ki izhaja iz t. i. problema okvirja kot problema za sisteme splošne umetne inteligence, je, da je človeška kognicija izrazito holistična in abduktivna (Fodor 2000), kar pomeni, da pri tvorbi naših prepričanj, oblikovanju (moralnih) sodb ali pri našem delovanju lahko upoštevamo zelo širok nabor informacij o ozadjih, prepoznamo tiste posebej relevantne in jih med seboj povezujemo (Horgan, Potrč in Strahovnik 2018). V okviru tradicionalne filozofske misli lahko to z drugimi besedami opišemo kot občutljivost in odzivnost na razloge. Širše so ti premisleki utemeljeni v misli Wilfrida Sellarsa in njegovem konceptu prostora razlogov - kot nečem različnem od prostora vzrokov, kjer gre le za verigo vzročnega učinkovanja in odzivanja, brez premisleka o razlogih (Sellars 1956, 169). To velja tako za spoznavne razloge (razloge, na podlagi katerih oblikujemo naša prepričanja), kot tudi za praktične razloge (razloge, na podlagi katerih delujemo oziroma oblikujemo naša dejanja), posledično pa tudi za etične razloge oziroma premisleke. To celotno domeno oblikovanja prepričanj, sodb in delovanja umeščamo v okvir prostora razlogov, saj lahko tako dejanja kot prepričanja upravičimo s sklicevanjem na razloge. To, da smo delovalci v prostoru razlogov (se pravi, da prepoznamo razloge, delujemo na njihovi podlagi in jih zmoremo $v$ zagovor tudi navesti), je značilno človeška oblika misli in delovanja.

Z vidika transhumanizma se zastavlja vprašanje, kakšne so možnosti nadgradnje te sposobnosti pri vključevanju umetne inteligence (ali vsaj tako imenovane ražsirjene kognicije oziroma razširjene misli) ter kakšne so načelne ovire, da bi oboje plodno združili. Vprašanje je tudi, v kakšni meri lahko umetni inteligenci in drugim podobnim sistemom pripišemo zmožnost odzivnosti na razloge ter v zvezi s tem pri teh sistemih govorimo o oblikovanju spoznavnih in moralnih vrlin. Osrednje vprašanje v okviru spoznavnih vrlin je, ali lahko človeško misel z umetno inteligenco modeliramo - vključno $z$ občutljivostjo na razloge. Sistemi, ki uporabljajo umetno inteligenco namreč delujejo na temelju velikega števila operacij, na podlagi obsežnega nabora podatkov ter s hitrostmi procesiranja informacij, ki znatno presegajo človeško, medtem ko človeško mišljenje pogosto poteka na podlagi predhodnih vzorcev ter zasledovanja pozornosti in pomembnosti, in torej deluje na precej drugačen način.

Ključno vprašanje v okviru (trashumanistične nadgradnje) moralnih vrlin je, ali bi takšne izpopolnjene moralne vrline sploh še zasledovale občutljivost na moralne razloge, posebej tudi z vidika tistih razlogov, ki jih v našem moralnem premi- 
sleku nismo (v celoti) upoštevali. Občutljivost na razloge vključuje prepoznavanje razlogov kot moralno relevantnih značilnosti situacije oziroma predmeta presoje, presojo o tem, na kakšen način ti razlogi vplivajo drug na drugega in kakšna je njihova teža ter kaj bi bilo glede celotno situacijo moralno pravilno oziroma kakšen bi bil najustreznejši moralni status predmeta naše presoje. Zgolj nadgrajene dispozicije za delovanje v skladu z nekaterimi vrlinami bi takšnemu prepoznavanju moralne pomembnosti dodelile sekundarno vlogo, saj bi program nadgradnje pri občutljivosti na razloge po novem določal bistveno smer. Nicholas Agar izpostavlja (en) problematični vidik takšne osiromašene občutljivosti na razloge:

„Naša občutljivost na moralne razloge, ki jih lahko sicer smiselno zavrnemo, je pomemben oziroma vreden del človeka. [...] Nekdo, ki je bil podvržen moralnemu izboljšanju, bo verjetno imel zmanjšano občutljivost za tiste razloge, ki jih zavrača ta, ki ga je izboljšal. $V$ tem smislu lahko to tudi ogrozi moralno raznolike liberalne demokracije, katerih uspeh temelji na vpogledih v različne in raznotere moralne motivacije članov te skupnosti.« (Agar 2010a, 75)

Tako se vzpostavlja morebiten kontrast med demokratično in pluralistično družbo na eni strani in (anti)utopično družbo, ki je enotna in nadzirana na drugi strani - v smislu, da nihče ne izstopa z vidika moralnih razlogov za delovanje oziroma od njih ne odstopa. Takšen ukrojen model »(super)etičnega « človeka lahko najdemo predvsem $v$ antiutopijah, vključno z enim izmed pomenljivejših prikazov nevarnosti osiromašenja moralnosti $v$ imenu ideje skupnega ali nekega dobrega $v$ romanu Aldousa Huxleya Krasni novi svet. Ne gre pa samo za razloge, ki jim v delovanju sledimo (npr. da smo bolj skrbni, pravični in iskreni), ampak tudi za razloge, ki jih sicer prepoznamo, jim lahko pripišemo smiselno pomembnost, a jih potem $v$ delovanju dejansko ne upoštevamo. Tudi takšno prepoznavo moramo razumeti kot del celostne etične vrlosti (na podlagi takšnih razlogov lahko na primer čutimo obžalovanje ali pa razumemo dejanja drugih ipd.). Nadgradnja etičnih vrlin bi lahko vodila v osiromašenje takšnega prostora razlogov.

Podobno, a nekoliko širše, opozarja tudi Daniels $(2009,40)$, ko izpostavlja, da so vrline izjemno zapletene človekove značilnosti, ki so tesno medsebojno prepletene in odvisne, hkrati pa so občutljive za okoliščine oziroma kontekst, terjajo medsebojno tehtanje ter vključujejo posebne načine zaznave, dojemanja in razumevanja. Čeravno so vrline tesno povezane z različnimi sposobnostmi ali dispozicijami, ki so njihova podlaga (npr. sočutje oziroma občutljivost za čustva drugih, inteligenca, umerjanje čustvenih odzivov) in na katere bi lahko vplivali z gensko tehnologijo, to ne pomeni, da bodo nadgrajene sposobnosti nujno prispevale k moralni vrlosti, kajti zlahka lahko postanejo tudi gradnik zlobnosti. Hkrati pa ni nobenega zagotovila, da se bo celoten sistem moralne vrlosti nadgradnji nekaterih vidikov oziroma sposobnosti zares ustrezno prilagodil. Willows (2017) tako opozarja, da tehnologije, ki jih za moralno izboljšanje predlaga transhumanizem, večinoma delujejo na nekatere dispozicije za delovanje v skladu s posameznimi vrlinami, vprašljivo pa je, ali delujejo v smeri celostne etične vrlosti. Obenem nobena izmed predlaganih tehnologij ne deluje v smeri tega, da bi si posameznik lahko odgovoril na vprašanje, 
kako mora ravnati v posamezni konkretni situaciji - ne izboljšujejo ali nadgrajujejo preudarnosti, razsodnosti ali praktične modrosti. Eno je, da določena genska sprememba ali farmakološko aktivna snov vpliva na raven našega sočutja ali skrbi, drugo pa, ali se na takšni podlagi znamo moralno pravilno odzvati v dani situaciji. Brez praktične modrosti tako ne moremo zares razumeti, kako in zakaj tako ravnati, kar pa je pri vrlosti cilj. Hkrati se praktična modrost izmika transhumanističnim projektom izboljšave intelektualnih vrlin in drugih kognitivnih spodobnosti, saj terja prakso in pristno občutljivost na posamezno situacijo.

V okviru premisleka o transhumanističnem projektu etične nadgradnje človeka moramo nujno izpostaviti tudi vidike človekove pluralnosti, svobode in avtonomije. Žalec v zvezi s tem poudarja, da »strahospoštovanje božjih zapovedi hkrati z zavestjo, da vere ne moremo zreducirati na nobeno Sittlichkeit, daje posamezniku moč, da nasprotuje ustaljenim normam in pogledom, to pa pomeni, da krepi njegovo avtonomnost in subjektivnost. Takšni posamezniki in takšno nasprotovanje so ključni za družbeni in demokratični razvoj. Brez njih je demokracija lahko kvečjemu abstraktna, ne pa dejanska. Abstraktna demokracija okosteni, se neha razvijati, njeni člani pa vedno bolj zapadajo v bolj ali manj prikrito golo pripadnost, ki se zlahka razvije $v$ fundamentalizem, kvietistični individualizem ali pa anarhizem.« (2017, 257-258) V luči tega bi transhumanistični projekt nadgradnje etičnih vrlin lahko ogrozil demokratične podlage človeške družbe.

Petkovšek (2018) izpostavlja tudi pomen simbolnosti v povezavi s svobodo in avtonomijo, pri čemer je posebej v ospredju odnos med svobodnim delovanjem in etičnostjo.

"Svoboda ni sama sebi cilj; človeku je dana kot okvir, kot forma, kot oblika, da bi v njej uresničeval svojo človeškost. Ta mu omogoča iskati resnico, delati dobro in živeti ljubezen. Resnica, dobrota in ljubezen imajo svoj izvor v svobodi; to, kar so, so lahko samo, če izvirajo iz svobodne odločitve. Računalnik rešuje zapletene probleme veliko hitreje kot človeški razum, a zanj ne rečemo, da je 'spoznal resnico'; tudi za zdravilo, ki ozdravi težko bolezen, ne rečemo, da je 'naredilo dobro delo'. V pravem pomenu besede spozna resnico ali dela dobro samo človek, ki se za to svobodno odloči. Rečemo lahko, da je svoboda humus, potreben za rast človeka v njegovi človečnosti.« (35)

Transhumanistični projekt nadgradnje etičnih vrlin bi izključeval takšno svobodo premisleka ali delovanja, saj bi našo odzivnost vnaprej programiral. Hkrati se ne moremo osredotočati zgolj na eno razsežnost (na primer vrline), ampak moramo celokupno zajeti celostnost človekovega življenja, kakor to na primer izpostavljajo razumevanja etike kot umetnosti življenja. Moralnost je zgolj eden izmed teh vidikov, kajti pomembno je tudi »razumevanje odnosa med čustvi, čustvovanjem, vrednotenjem in vzpostavljanjem dobrega življenja. V okviru umetnosti življenja je pomembno to, da posameznik ozavešča in pretresa procese čustvovanja kot vrednotenja ter jih vpenja v moralnost. Začetek tega procesa pomeni refleksi- 
ja svojih lastnih čustev, ki se človeku razkrivajo ob njegovih pomembnih ciljih in v pomembnih odnosih « (Centa 2018, 61) Tudi ta celostni vidik etičnosti in dobrega življenja je trenutno $v$ okviru projektov moralnega transhumanizma bolj ali manj spregledan. Projekt moralnega transhumanizma tako (lahko) siromaši prostor razlogov, našo odzivnost nanje, s tem pa tudi človekovo svobodo in avtonomijo, v katerih etika šele zares dobi svoj smisel.

\section{Reference}

Agar, Nicholas. 2010a. Enhancing genetic virtue? Politics and the Life Sciences 29, št. 1:73-75.

- - 2010b. Humanity's end: why we should reject radical enhancement. Cambridge, MA: Bradford/MIT Press. https://doi.org/10.7551/mitpress/9780262014625.001.0001

Aristotel. 2002. Nikomahova etika. Ljubljana: Slovenska matica.

Bostrom, Nick in Anders Sandberg. 2009. The Wisdom of Nature: An Evolutionary Heuristic for Human Enhancement. V: Savulescu in Bostrom 2009, 375-416.

Bostrom, Nick, in Eliezer Yudkowsky. 2014. The ethics of artificial intelligence. V: Keith Frankish in William Ramsey, ur. Cambridge Handbook of Artificial Intelligence, 316-334. New York: Cambridge University Press.

Caplan, Arthur L. 2009. Good, Better, or Best? V: Savulescu in Bostrom 2009, 199-209.

Centa, Mateja. 2018. Kognitivna teorija čustev, vrednostne sodbe in moralnost. Bogoslovni vestnik 78, št. 1:53-65.

Cruz, Joe. 2019. Shared Moral Foundations of Embodied Artificial Intelligence. V: Proceedings of the Association for the Advancement of Artificial Intelligence. http://www.aies-conference.com/wp-content/papers/main/AIES-19_ paper_52.pdf (pridobljeno 18. 6. 2019). https:// doi.org/10.1145/3306618.3314280

Daniels, Norman. 2009. Can Anyone Really Be Talking About Ethically Modifying Human Nature? V: Savulescu in Bostrom 2009, 25-42.

Douglas, Thomas. 2008. Moral Enhancement. Journal of Applied Philosophy 25, št. 3:228-245.

Fodor, Jerry. 2000. The Mind Doesn't Work That Way. Cambridge, MA: MIT Press.

Globokar, Roman. 2018. Krščanski antropocentrizem in izkoriščevalska drža človeka do naravnega okolja. Bogoslovni vestnik 78, št. 2:349364.

Horgan, Terence, Matjaž Potrč in Vojko Strahovnik. 2018. Core and Ancillary Epistemic Virtues. Acta Analytica 33, št. 3:295-309. https://doi.org/10.1007/s12136-018-0349-4
Hursthouse, Rosalind, in Glen Pettigrove. 2018. Virtue Ethics. V: The Stanford Encyclopedia of Philosophy. Ur. Edward N. Zalta. https://plato. stanford.edu/archives/win2018/entries/ethics-virtue/ (pridobljeno 18. 6. 2019).

Persson, Ingmar, in Julian Savulescu. 2008. The Perils of Cognitive Enhancement and the Urgent Imperative to Enhance the Moral Character of Humanity. Journal of Applied Philosophy 25, št. 3:162-77. https://doi. org/10.1111/j.1468-5930.2008.00410.x

Petkovšek, Robert. 2018. Svoboda med žrtvovanjem in darovanjem. Bogoslovni vestnik 78, št. 1:33- 51 .

Savulescu, Julian. 2009. The Human Prejudice and the Moral Status of Enhanced Beings: What Do We Owe the Gods? V: Savulescu in Bostrom 2009, 211-247.

Savulescu, in Nick Bostrom, ur. 2009. Human enhancement. New York: Oxford University Press.

Sellars, Wilfrid. 1956. Empiricism and the philosophy of mind. V: Wilfrid Sellars. Science, perception, and reality, 129-194. London: Routledge and Kegan Paul.

Strahovnik, Vojko. 2016. Razsežnosti intelektualne ponižnosti, dialog in sprava. Bogoslovni vestnik 76, št. 3/4:471-482.

Walker, Mark. 2009. Enhancing genetic virtue: A project for twenty-first century humanity? Politics and the Life Sciences 28, št. 2:27-47. https://doi.org/10.2990/28_2_27

Willows, M. Adam. 2017. Supplementing Virtue: The Case for a Limited Theological Humanism. Theology and Science 15, št. 2:177-187. https:// doi.org/10.1080/14746700.2017.1299375

Žalec, Bojan. 2010. Človek, morala in umetnost: uvod v filozofsko antropologijo in etiko. Ljubljana: Teološka fakulteta.

- - - 2017. Kierkegaard in politično: vera kot premagovanje nasilja in vir demokracije. Bogoslovni vestnik 77, št. 2:247-259. 